DOI: doi.org/10.21009/IJLECR.071.06

Received: 4 November 2020

Revised: 9 March 2021

Accepted: 29 June 2021

Published: 30 June 2021

\title{
IMPROVING EFL NON-ENGLISH TEACHERS IN TEACHER TALK ABILITY THROUGH TEACHERS' TRAINING AT SD TUNAS GLOBAL
}

\author{
Dini Handayani ${ }^{1, a)}$ \\ Universitas Borobudur ${ }^{1)}$ \\ Dini_handayani@borobudur.ac.id ${ }^{\mathrm{a})}$
}

\begin{abstract}
Foreign curriculum in Indonesian schools becomes more in demand. The schools facilitate the teachers with the students' books written in English. The teachers must deliver the lesson in the correct English in the classroom. Not all the teachers know that English for teaching differs from daily English. Since SD Tunas Global combined the new curriculum from Cambridge in the education year 2020-2021 with the government curriculum, using English to use inside and outside the classroom is a must. Phenomena often appeared from the observation where teachers often used the mother-tongue language, Bahasa Indonesia. They tend to translate Bahasa Indonesia into English without knowing whether the speech was proper English to use in teaching. Teacher talk is the sentences and expressions that can be used both inside and outside the classroom. The data were taken from the interview, observation, and the result from can use this research employed qualitative and quantitative method.
\end{abstract}

Keywords: teacher talk; elementary school; teaching; elementary school's teachers.

The number of non-English teachers that is needed to teach all subjects in English is demanded, especially in private schools. Parents tend to expect their children to be fluent in English; therefore, they enrol their children on expensive schools that are hoping to expose this language more. Since the classroom is the main place to learn and expose English, all teachers need to have skill in conducting the materials and managing the classroom. Teacher talk refers to the teachers' talk to the students about all the activities at the school. Language in the EFL classroom is the primary purpose and the tool to deliver the lesson (Walsh, 2002). From the teacher talk, students also learn how English used in the contextual situation. Greetings, checking the attendance, organising the classroom, ending the lesson, giving instruction in English, phrasing, explaining and showing the lesson are some of the teacher's talks employed in the classrooms (Mary Slattery and Jane Willis 2001).Teachers know that the true praises are better to give to the students for the specific actions ( Knoll and Patti' 2003,). It is better for the teachers to say " excellent for that painting. It is beautiful" instead of just" very good". The effects of using teacher talks also give the impact to the students to be more diligent and want to do the best. The importance of follow-up and feedback in the learning process are crucial to the students' result (Cullen 2002). Praisings and other supportive feedback from the teachers reflect on the students' progress.

There had been some studies to be conducted in terms of training the teachers to get familiar with the teacher talk, such as Nurhasanah (2017) conducted a research and a training for 
several non-English teachers in one of the Islamic elementary schools in Bandung. The researcher concluded that the training would be more successful if the materials were systematically arranged in order based on the teacher's need, evaluated the teachers' result before and after the training, and invited the native speaker to this training. Another research was done by Fitriati and Farida (2017) in one of the private Elementary school in Semarang. The school adopted bilingualdeliver the lesson. The training, was conducted in five sessions with 2 until 2,5 hours in each session. The result was still far from the expectation since lack of exposure. The researcher suggested that the next teacher's training should separate the teachers into two classes; elementary level and intermediate level. Micro teaching is also needed to measure the teachers' speaking skill at the end of the training. Rosita (2017) also conducted the research with questionnaire which was answered by the several classroom's teachers. The research indicated that $43,6 \%$ of classrooms' teachers need speaking training and $25,5 \%$ of them said writing skill is needed at the moment. Out of $32,9 \%$ classrooms' teachers wish to speak with their students using English and 21,9\% of them wish they could use English to talk with their fellow classrooms' teachers. This research aims all the teachers in SD Tunas Global can use teacher's talk in the classroom, so that the students can be familiar with English. Summing up what is noted in the background, the problem of the research is Does teacher talk can be improved to EFL Non-English teachers at SD Tunas Global in teacher's training?

\section{Literature Review Adult learners}

The need to identify the learners is important to achieve the aim of this short training. This short training was joined non-English teachers aged 25 until 64 years old which are categorized as adult learners (Blumenstyk, 2018). Adult learners need to have simple language to understand during the short course, short time to join the course, the time to join the course can be negotiated again if they can not join the course, the language to use to call down them is done with the polite and low intonation, and their lives can be improved by this training (Pavlovian behaviorist approach cited in Simonson, Smaldino, Albright, \& Zvacek, 2012; Anderson, 2008). This training was to give more knowledge to the non English teachers so that they can implement in front of the classroom. This teachers' training only focused on sentences that are usually used by teachers. Turney, as cited in Madjid (2019) sets nine (9) teaching skills of teachers, namely: (1) start the lesson skill, (2) End the lesson skill, (3) Asking skills, (4) Skills in providing reinforcement, (5) Skills to make variations, (6) Skills in explaining, (7) Skills to open and close lessons, (6) Skills to guide small group discussions, (8) Management class skills, and (9) small group and individual teaching skills. In line with Turney, Usman (2017) mentioned 9 (nine) teaching skills in teachers area, namely: (1) Skills in opening lessons, (2) Asking skills, (3) giving strengthening skills (4) Skills to provide variety, (5) Explanation skills,(6) Skills to guide small group discussions, (7) Skills managing the class, (8) individual teaching skills, and (9) skills to close the lesson.Those skills are suitable for the non English teachers at SD Tunas Global to convey the learning process becomes better.

\section{Young learners}

The non English teachers who were going to join this short course were elementary school's teachers. These non English teachers are usually teaching the young learners aged 7 until 12 years in age. These elementary's pupils have their own characteristics to learn how to write and read in their own mother tongue language, start to ask questions on everything, between the real situation or fantasy, able to work with peers and able to do the school activities (Slatterly, M., \& Willis, J. (2001). The researcher prepared the teacher's talk that was easily understood by both the non 
English teachers and the young learners. The teacher must know what the teacher's talk should be used in the class to make the students more motivated..In other words, the correct teacher's talk can make the students interested to learn (Gharbavi and Iravani 2014). Using the correct teacher's talk not only to get the students to be motivate but also can make the non English teachers' knowledge increased.

\section{METHOD}

This research employed classroom action research which was directly made changes in the reason of using this method is to see how far these non English teachers absorb the knowledge in the teacher's talk. Classroom action research was decided in three cycles and to be implemented in this research due to the directly changes made in the classroom (Lodico, Spaulding, \& Voegtle,2010). The data in this research were observation was done to see the teachers' intake to absorb the teacher's talk through this training, interview, audiovisual, pictures and evaluation through the achievement test which was analysed by the researcher. The researcher made the observational checklist to identify the data related to the aspects of teacher's talk. Another instrument that was used in this research was interview. The interview was focused on teacher's problem in using teacher's talk and was done in Bahasa Indonesia to make clearer and more comfortable with flexible questions. All thirteen were being interviewed by the researcher before the training. Audiovisual and pictures were employed to get clearer the data. The data analysis in this research divided into several stages such as transcribing the recorded interview, the recorded classroom observation, observation field note into written form and calculated the test before and after the research. After all the data were analyzed, the researcher interpreted the data by calculating the total of each indicators in teacher's talk.

\section{RESULTS AND DISCUSSION}

The observation was used to find out the ability of non English teachers in the classroom. These non-English teachers were teaching online due to the Corona pandemic. It was held on August 8th, 2020. During this observation, the problems arose from the non-English teachers in teaching. Most of them can only say the greetings and to give compliments by saying good. They found difficulties in other expressions, such as asking the students to do something, organising the classroom, and ending the classroom. This observation was done in a month and all these teachers felt more confidence in using Bahasa Indonesia. After the observation, the researcher conducted the interview session with these teachers. It was revealed that the teacher hardly said and pronounced the expressions in the classroom due to lack of knowledge in English. Before starting the training, the researcher applied the handout of teacher's talk used in Australian schools. The 11-page handouts contain several expressions in teacher's talk such as greeting, checking the attendance, organizing the classroom, explaining the lesson, etc. The research was completed in three cycles with two meetings in each cycle. The researcher in this training also acted as the tutor. At the beginning of the first cycle, August 10th, 2020, the teachers had given the pre-test. This test was to find out the knowledge of teachers in the area of teacher talk. After that, the researcher started to explain kinds of teacher's talk that can be used in front of the class. In the second meeting of the first cycle, the researcher asked several teachers to come in front of the class to practice it. Out of 13 teachers who joined the test, only 2 of them able to get 80 and one of them got 7.3. Two teachers were absent due to the Independence Day's recording event. The second cycle was supposed to be on August 12th, 2020, but it was postponed due to the Independence Day's meeting. Then the headmaster rescheduled to August 14th, 2020. In the second cycle, the number of teachers who entered the second training was complete. The researcher explained the teacher's talk again and gave ten classroom problems to several teachers in random, The teachers must find 
out what kind of teacher talk suitable for each problem. The non-English teachers ware having a break and continued the fourth meeting. After all, they gave their opinions on the best in teacher's talk; the researcher gave some feedback. The third meeting was supposed to be on August 14th, 2020 but had to be postponed again because the teachers had the Independence day's event. The headmaster asked the researcher to have the last day of the training on August 28th, 2020. Ten teachers attended the last training day. Three teachers were absent due to family business and checking the students' online assignments. On the last day of training, the researcher asked several non-English teachers to come up in front of the class. Some of them acted as the students, and some of them acted as the teacher. After the role-play, the researcher gave a chance to others who did not join the role-play to give some opinions. The last day of training was ended up with the Post-Test. Four of the teachers got 70 until 100. They have some improvement on their abilities. The result of the test are presented in the following table :

Table 1

The Result of the Pre-test and Post Test scores

\begin{tabular}{|c|c|c|c|}
\hline No. & Subject & $\begin{array}{c}\text { Pre-Test } \\
\text { (IR) }\end{array}$ & $\begin{array}{c}\text { Post Test II } \\
\text { (R2) }\end{array}$ \\
\hline 1 & MLV & 6.7 & 7.0 \\
\hline 2 & MLP & 3.3 & 8.0 \\
\hline 3 & LN & 4.7 & 5.0 \\
\hline 4 & WY & 8.0 & 4.0 \\
\hline 5 & EK & 7.3 & 6.0 \\
\hline 6 & ST & 8.0 & 10.0 \\
\hline 7 & NR & 4.0 & 6.0 \\
\hline 8 & YR & 4.7 & - \\
\hline 9 & SD & - & 8.0 \\
\hline 10 & HD & 5.3 & 60 \\
\hline 11 & SA & 4.0 & - \\
\hline 12 & LL & 4.7 & 6.0 \\
\hline 13 & AK & - & 66 \\
\hline
\end{tabular}

\section{Procedures}

After collecting the data, the researcher processed the data. Then, the researcher tried to count the percentage of a success indicator and mean score to get the specific and honest data.

\section{Discussion}

The curriculum that thie school is going to adopt is the combination between the international and local curriculum. Conducting this training is a very crucial to support the school as well as the teachers' knowlledge. The last stage was to decide whether the research is success or need to be improved. The success indicator is from $85 \%$ out of the total number of participants who joins the research. It means that if $85 \%$ of the learners or more gets the passing scores, the research is successful, but if less than $85 \%$ of the learners receive below than the passing grade, that means the techniques can not be used to improve the teachers' ability (Rusman and Rahman 2010). The passing grade for the present study was 7.0 for the pre-test and post test. The research shows the scores that were not indicated the successful progress. Altough the test results were far from the expectation, the observation and interview results were diffrently. During the training session, most of the teachers engaged to learn by giving their comments on what was happened in the classroom 
based on their experiences and giving the feedback to their teachers' friends. The interview was conducted in their break time and the teachers eargerly wanted to join the training by saying the dates for the training was still long. They demanded to the resaercher to change the dates. After the researcher explained to them that the dates were from the headmaster, the teacher followed the dates. The motivation and goals are the two things to make the learners eager to study harder (Aberdeen 2016). The teachers who joined this training were had to join the training due to the school's curriculum which will be used in the foreign curriculum along with the government's.. The teachers actually motivated to learn but after they hear there isn't any impact for their career path nor their incomes that makes the teachers' motivation fade away. The teachers' age who joined this training also senior teachers. As Smith stated the perfect age to start to learn language is before 10 years old (Smith 2018). The teachers' ages in this school are mostly above 35 years old. So it is a bit difficult to learn the language.

\section{Conclusion}

\section{CONCLUSION}

Teacher talk is very useful for teacher to explain and give command to the students both inside and outside classroom. Without motivation and goals in the learning process showed an unsatisfactory result. It is supported by the result of the pre test (60.7), and the result of the post test (66). Teacher's talk is the sentences and expressions which are special to use for teaching in all subjects.

\section{Implication}

The implications of this research are presented as follow:

1. The teacher talk training was not working well due to the lack of motivation and goals from the school.

2. The time for learning teacher talk was very short, so it makes the learners difficult to learn.

3 . The length of time from the first meeting until the last meeting was too far.

\section{Suggestion}

\section{For the teacher :}

Since teacher talk is very important to be mastered by the teacher, the researcher hopes the teachers can learn and imply in teaching.

\section{For School institution :}

The school has to give rewards to the teacher who can apply teacher talk in front of the classroom so the teachers have motivation and goals to learn it.

\section{For other researcher :}

The result can be higher than this research's result if the period of time to conduct the actions are longer.

\section{REFERENCES}

Aberdeen, I.H, 2016. How long does it take to learn English?. Retrieved on September5th, 2020 from www.iharberdeen.com

Anderson, T. (2008). Teaching in an Online Learning Context. In T. Anderson,The Theory and Practice of Online Learning, 2nd ed.(pp. 343-365). Edmonton: AU Press.

Blumenstyk, Goldie. The Adult Student: The Population Colleges - and the Nation-Can't Afford to Ignore. The Chronicle of Higher Education, 2018.

Cullen, R. (2002) Supportive teacher talk: the importance of the follow-up in English language 
teaching.Vol.53. Oxford: Oxford University Press Pp.117

Fitriati, W. S., Farida, N. A. 2017. Peningkatan Kompetensi Guru Dalam Speaking English For Instructional Purposes Untuk Pengajaran Bilingual di SD Islam AL Azhar 29 BSB Semarang.

Gharbavi, A., \& Iravani, H. (2014). Is the teacher talking pernicious to students? a discourse analysis of teacher talk. Procedia - Social and Behavioral Sciences 98, 552-561.

Knoll, M. and J. Patti. 2003.. "Social-Emotional learning and academic achievement". In M.J. Elias, H.Arnold and C.steiger Hussey. EQ+ IQ = Best Leadership Practices for caring and successful schools.Thousand Oaks, CA: Corwin press pp.42.

Lodico,M.,Spaulding,D.\& Voegtle ,K.(2010).MethodsinEducationalResearch: From Theory to Practice,2nd Edition.SanFrancisco,CA:Jossey-Bass.

Madjid, A. 2019 Kompetensi Profesional Guru: Keterampilan Dasar Mengajar. Studies in Journal Peqguruang: Conference Series e-ISSN: XXXX-XXXX Vol 1, No.1 May 2019

Nurhasanah, S. 2017. Pelatihan Peningkatan Kompetensi Berbahasa Inggris Guru Dalam Pembelajaran Bilingual di SDIT Bilingual Fithrah Insani Kabupaten Bandung Barat.

Rosita, E. 2017. Analisis Kebutuhan Bahasa Inggris Guru Kelas.

Rusman and Abdurahman 2010. Panduan Pengembangan Profesi Guru dan PTK. Karima. Depok.

Simonson, M., Smaldino, S., Albright, M., \& Zvacek, S. (2012).Teaching and Learning at a Distance (5th ed.). Boston: Pearson Education, Inc.

Smith, G, Dana. 2018. At What Age Does Our Ability to Learn a New Language Like a Native speaker Disappear? Retrieved on September 5th, 2020 from www.americanscientific.com

Slatterly, M., \& Willis, J. (2001). English for primary teachers. Oxford: Oxford University Press.

Usman, Moh. Uzer. 2017. Menjadi Guru Profesional, Bandung: Remaja Rosdakarya.

Walsh, S (2002) Construction or Obstruction: teacher talk and learner involvement in the EFL classroom.Language Teaching Research 6/1.pp. 3-23. 